10IKC-078

\title{
TECTONIC RELATIONSHIPS BETWEEN CRATONIC AND ULTRA-HIGH PRESSURE (UHP) DIAMOND - IMPLICATIONS FOR CRATON FORMATION AND STABILIZATION
}

\author{
H.H. Helmstaedt \\ Department of Geological Sciences and Geological Engineering, Queen's University, Kingston, Ontario, Canada K7L $3 N 6$
}

\section{INTRODUCTION}

As economic kimberlites and lamproites are located almost exclusively on or near Archean cratons (Janse, 1994), their diamonds are commonly referred to as cratonic (e.g. Stachel and Harris, 2008). Close to $99 \%$ of such diamonds are derived from peridotitic and eclogitic source rocks in the subcontinental lithospheric mantle (SCLM), and Archean to Proterozoic mineral inclusion ages (reviewed by Gurney et al., 2010) suggest that they are xenocrysts within their normally much younger igneous transport media. It is generally assumed that growth events of cratonic diamonds are closely related to the formation and early modifications of the cratonic roots in which they are stored. A subduction origin for many of the eclogitic diamond sources and coesite-bearing eclogites (Fig. 1) is now well established (e.g. Schulze and Helmstaedt, 1988; Schulze et al., 2000, 2003; Jacob, 2004), and should be an integral part of tectonic models explaining the origin of such roots.

UHP diamonds occur in Phanerozoic subduction melanges, consisting mainly of continental crustal rocks that were subducted to depths of up to $140 \mathrm{~km}$ and subsequently exhumed tectonically within relatively brief time spans of 10-20 million years (Coleman and Wang, 1995; Ernst, 2006). Diamond, where present, is generally preserved only as micro-inclusions encapsulated in zircon, garnet, clinopyroxene and kyanite within pelitic schist, paragneiss, whiteschist, eclogite and metacarbonate (Ogasawara, 2005). Cratonic and UHP metamorphic diamonds differ vastly in properties, quality and size, and they lie on different ends of the geological age spectrum. Yet in spite of these differences, it is proposed here that certain eclogitic host rocks of cratonic diamonds are the Precambrian counterparts of Phanerozoic UHP eclogites. Implications for the debate about lithosphere formation and stabilization as well as plate margin processes on the Mesoarchean Earth are discussed.

\section{UHP METAMORPHISM BEGAN IN THE MESOARCHEAN}

Recent reviews show that occurrences of UHP collisional complexes in the surface geological record are restricted to $\sim 1 \mathrm{Ga}$ and younger crust (e.g. Ernst, 2006, 2009). On the other hand, a number of authors have conjectured that diamond- and coesite-bearing eclogite xenoliths from kimberlites are expressions of earlier UHP metamorphic events (e.g. Santosh et al., 2009; Helmstaedt et al., 2010). Although both assemblages may contain coesite and/or diamond, the major index minerals for what has been defined as UHP metamorphism (Coleman and Wang, 1995), there nevertheless appears to be a great reluctance to explore potential analogies between them and perhaps establish a unified tectonic model. 


\section{$1^{\text {th }}$ International Kimberlite Conference, Bangalore - 2012}

One of the key observations regarding the tectonic setting of UHP diamonds is that they occur in fossil subduction scars, but are confined to domains in which subduction of ocean floor was followed by continental or microcontinental collision (Maruyama et al., 1996). Exhumed UHP melanges thus consist mainly of sheets of relatively low density and therefore 'unsubductable' quartzofeldspathic and calcareous rocks with less than $10 \%$ of lenses of eclogitic and peridotitic rocks. The extreme rarity of diamond-bearing UHP assemblages in the Phanerozoic record is an indication that exhumation and subsequent preservation were exceptions rather than the rule, posing the question as to fate of the higher-density ocean floor rocks that were subducted prior to continental or microcontinental collision. These may be assumed to pile up as megaliths or slab graveyards near the transition zone or accrete in part to the roots of cool Precambrian cratons. In rare instances, Phanerozoic UHP products have been exhumed by igneous rocks, such as coesitebearing eclogites in the ca. $30 \mathrm{Ma}$ Navajo diatremes of the Colorado Plateau (e.g. Usui et al., 2003), or macrodiamonds of inferred subduction origin that were transported to the surface by Tertiary alkaline igneous rocks in eastern Australia (e.g. Barron et al., 2005, 2008).

A possible case for a Precambrian exhumation of UHP subduction diamonds by igenous rocks was made by Cartigny et al. (2004) for E-type microdiamonds from the $1.832 \mathrm{Ga}$ Akluilak minette dyke, Baker Lake area, Nunavut, Canada. This inference was based on the observation that the diamonds do not show wellaggregated nitrogen centers as would be expected from cratonic diamonds with long residence times in the mantle (Chinn et al., 2000).

UHP eclogites and mantle eclogites are thus thought to represent complimentary end products of the same tectonic process. Both may begin their UHP metamorphic history in the same subduction zone, but the former are exhumed together with crustal assemblages soon after continental or microcontinental collision. The latter are derived from the oceanic parts of the subducting slab and continue their downward journey. They may accrete to continental roots, but are exhumed only if picked up by younger igneous transport media (i.e. kimberlites, lamproites, etc.). As shown by $\sim 2.9 \mathrm{Ga}$ ages of the oldest known eclogitic diamonds with subduction signatures, occurring in host rocks with even older mantle extraction ages (e.g. Gurney et al., 2010; Shirey and Richardson, 2011), the process of tectonic subcretion to continental roots began in the Mesoarchean, latest at ca. $3 \mathrm{Ga}$.

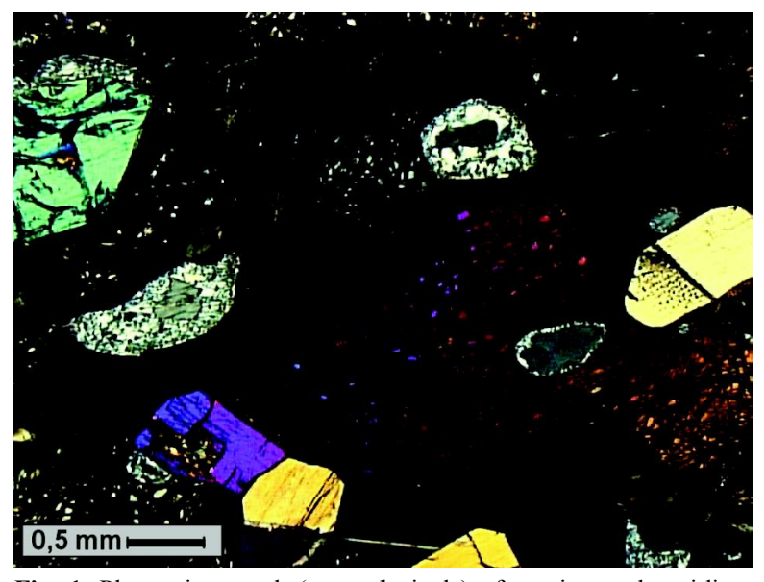

Fig. 1. Photomicrograph (crossed nicols) of coesite- and sanidinebearing grospydite (calcic garnet and kyanite bearing eclogite) xenolith from the Roberts Victor mine, South Africa. This xenolith was first described by Smyth and Hatton (1977), though its subduction origin was not recognized until later. Coesite grains (marked by white arrows) are surrounded by retrogressive polycrystalline quartz rims. Coesite, sanidine (upper left) and kyanite (lower and right part of photomicrograph) are set in a matrix of altered clinopyroxene and garnet

\section{MESOARCHEAN PLATE REGIMES}

The question of how and when plate-tectonic processes began on Earth has been debated at great length in the literature. Ernst (2009) pointed out that the problem is essentially one of terminology, for mantle circulation beneath a mobile outer rind has been in progress ever since the beginning of solidification of the latest magma ocean. The argument can thus be rephrased as to when 


\section{0 $^{\text {th }}$ International Kimberlite Conference, Bangalore - 2012}

lithosphere-asthenosphere interactions began to resemble more modern plate-margin processes. The appearance of eclogitic UHP metamorphic assemblages at ca. $3 \mathrm{Ga}$ demands that $>3 \mathrm{Ga}$ microcontinental nuclei (small cratons) where coupled to lithospheric roots sufficiently thick and cool to reach into the diamond stability field. This local lowering of geothermal gradients was likely achieved by large-scale tectonic imbrication of lithospheric slabs, as envisaged earlier by Helmstaedt and Schulze $(1988,1989)$ and de Wit et al. (1992) and now seen in Lithoprobe reflection seismic profiles of Archean cratons (e.g. Calvert and Ludden, 1999; White et al., 2003). However, the survival of ca. 3 Ga UHP metamorphic assemblages resulting from early subduction processes should not be construed as the beginning of plate tectonics in the modern sense, including the onset of Wilson cycles. Continental plates large enough to have the requisite freeboard for developing passive margin sequences did not evolve before the end of the Archean, and it likely took longer before the entire Earth surface was covered by rigid plates as we see them throughout much of the Phanerozoic.

\section{STABILIZATION OF EARLY LITHOSPHERIC ROOTS}

Considering the high mobility of the Archean lithosphere, it is remarkable that many of the ca. $3 \mathrm{Ga}$ micro-continental nuclei retained remnants of their $>3$ Ga roots throughout their post-Mesoarchean tectonic history. Indeed the worldwide harzburgitic P-type diamond budget is derived entirely from these roots. Reasons commonly invoked for the survival of the roots are the refractory nature and the slightly lower density of the harzburgitic component with respect to the surrounding, more fertile lherzolitic mantle. However, until revealed recently through reflection seismic sections under the Archean Slave Province, the role of Paleoproterozoic tectonic underplating in protecting and stabilizing the earlier roots was not fully appreciated. It now appears that significant parts of the eclogitic diamond budgets of kimberlites and lamproites may be derived from post-Archean amagmatically subducted material.

\section{References}

Barron, L. M., Barron, B. J., Mernagh, T. P., and Birch, W. D. (2008) Ultrahigh pressure macro diamonds from Copeton (New South Wales, Australia), based on Raman spectroscopy of inclusions. Ore Geology Reviews, v. 34, pp. 76-86.

Barron, B. J., Barron, L. M., and Duncan, G. (2005) Eclogitic and ultrahigh-pressure crustal garnets and their relationships to Phanerozoic subduction diamonds, Bingara area, New England fold belt, Eastern Australia. Economic Geology, v. 100, pp. 1565-1582.

Calvert, A. J., and Ludden, J. N. (1999) Archean continental assembly in the southeastern Superior Province of Canada. Tectonics, v. 18, pp. 412-429.

Cartigny, P., Chinn, I., Viljoen, F., and Robinson, D. N. (2004) Early Proterozoic ultrahigh pressure metamorphism: Evidence from microdiamonds. Science, v. 304, pp. 853-855.

Chinn, I., Kyser, K., and Viljoen, F. (2000) Microdiamonds from the Thirsty Lake (Akluilak) dykes, Northwest Territories, Canada. Cambridge Publications, v. 5 (2), pp. 307-308.

Coleman, R. G., and Wang, X., eds. (1995) Ultrahigh Pressure Metamorphism. Cambridge University Press, Cambridge, UK, 510 pp.

de Wit, M. J., De Ronde, C. E. J., Tredoux, M., Roering, C., Hart, R. J., Armstrong, R. A., Green, R. W. E., Peberdy, E., and Hart, R. A. (1992) Formation of an Archean continent. Nature, v. 357, pp. 553-562.

Ernst, W. G., and Liou, J. G. (1999) Overview of UHP metamorphism and tectonics in well-studied collisional orogens. International Geology Review, v. 41, pp. 477-493.

Ernst, W. G. (2006) Preservation/exhumation of ultrahigh-pressure subduction complexes. Lithos. v. 92, pp. 321-335.

Ernst, W. G. (2009) Archean plate tectonics, rise of Proterozoic supercontinentality and onset of regional, episodic stagnant-lid behavior. Gondwana Research, v. 15,p p. 243-253. 


\section{$1^{\text {th }}$ International Kimberlite Conference, Bangalore - 2012}

Gurney, J. J., Helmstaedt, H., Richardson, S. H., and Shirey, S. B. (2010) Diamonds through time. Economic Geology, v. 105, pp. 689-712.

Helmstaedt, H. H., Gurney, J. J., and Richardson, S. H. (2010) Ages of cratonic diamond and lithosphere evolution: constraints on Precambrian tectonics and diamond exploration. Canadian Mineralogist, v. 48, pp. 1385-1408.

Helmstaedt, H. H., and Schulze, D. J. (1989) Southern African kimberlites and their mantle sample: implications for Archean tectonics and lithosphere evolution, in Ross, J., ed., Kimberlites And Related Rocks, Proceedings of IV Kimberlite Concerence, Perth 1986, vol. 1, Geological Society of Australia, Special Publication 14, pp. 358-368.

Helmstaedt, H. H., and Schulze, D. J. (1988) Eclogitefacies ultramafic xenoliths from Colorado Plateau diatreme breccias: Comparison with eclogites in crustal environments, evaluation of the subduction hypothesis, and implications for eclogite xenoliths from diamondiferous kimberlites, in Smith, D. C., ed., Eclogites and Eclogite-Facies Rocks, New York, Elsevier, pp. 387-450.

Jacob, D. E. (2004) Nature and origin of eclogite xenoliths from kimberlites. Lithos, v. 77, pp. 295 316.

Janse, A. J. A. (1994) Is Clifford's Rule still valid? Affirmative examples from around the world. In Meyer, H. O. A., and Leonardos, O., eds., Diamonds: Characterization, Genesis and Exploration. Proceedings of the Fifth International Kimberlite Conference 1991, Araxa, Brazil, vol. 2, CPRM Special Publication 1B, pp. 215-235.

Maruyama, S., Liou, J. G., and Terabayashi, M. (1996) Blueschists and eclogites of the world and their exhumation. International Geological Review, v. 38, pp. 485-594.

Ogasawara, Y. ( 2005) Microdiamonds in ultrahighpressure metamorphic rocks. Elements, v. 1, pp. 91-96.

Santosh, M., Maruyama, S., and Omori, S. (2009) A fluid factory in solid Earth. Lithosphere, v. 1, pp. 29-33.

Shirey, S. B., and Richardson, S. H. (2011) Start of the Wilson cycle at $3 \mathrm{Ga}$ shown by diamonds from subcontinental mantle. Science, v. 333, pp. 434436.

Schulze, D. J., and Helmstaedt, H. (1988) Coesitesanidine eclogites from kimberlite: Products of mantle fractionation or subduction. Journal of Geology, v. 96, pp. 435-443.

Schulze, D. J., Valley, J. W., and Spicuzza, M. J. (2000) Coesite eclogites from the Roberts Victor kimberlite, South Africa. Lithos, v. 54, pp. 23-32.

Schulze, D. J., Harte, B., Valley, J. W., Brenan, J. M., and Channer, D. M. D. (2003) Extreme crustal oxygen isotope signature preserved in coesite in diamond. Nature, v. 423, pp. 68-70.

Stachel, T., and Harris, J. W. (2008) The origin of cratonic diamonds - Constraints from mineral inclusions. Ore Geology Reviews, v. 34, pp. 5-32.

White, D. J., Musacchio, G., Helmstaedt, H. H., Harrap, R. M., Thurston, P. C., van der Velden, A. J., and Hall, K. (2003) Images of a lower-crustal oceanic slab: Direct evidence for tectonic accretion in the Archean western Superior province. Geology, v. 31, pp. 997-1000.

Usui, T., Nakamura, E., Kobayashi, K., Maruyama, S., and Helmstaedt, H. (2003) Fate of the subducted Farallon plate inferred from eclogite xenoliths in the Colorado Plateau. Geology, v. 31, pp. 589-592. 